\title{
Robust
}

\author{
Research Business and Economics Studies
}

journal homepage: http://ejournal.iainkendari.ac.id/robust

\section{IMPLEMENTASI PEMBIAYAAN KREDIT USAHA RAKYAT (KUR) MIKRO SYARIAH DALAM PENGEMBANGAN USAHA MIKRO}

\author{
${ }^{1}$ Abdul Wahid Mongkito, ${ }^{2}$ Trisno Wardy Putra, ${ }^{3}$ Muhammad Imran, ${ }^{4}$ Kiki Novita, ${ }^{5}$ Andi \\ Nasrawati Ansar \\ ${ }^{1,3,4,5}$ Fakultas Ekonomi dan Bisnis Islam-IAIN KENDARI \\ ${ }^{2}$ UIN Alaudin Makassar \\ Email: ${ }^{1}$ wahid.mongkito@iainkendari.ac.id; ${ }^{2}$ trisno.putra@uin-alauddin.ac.id; ${ }^{3}$ muhimran@iainkendari.ac.id; \\ ${ }^{4}$ kikinovita@iainkendari.ac.id; ${ }^{5}$ andinasrah99@gmail.com
}

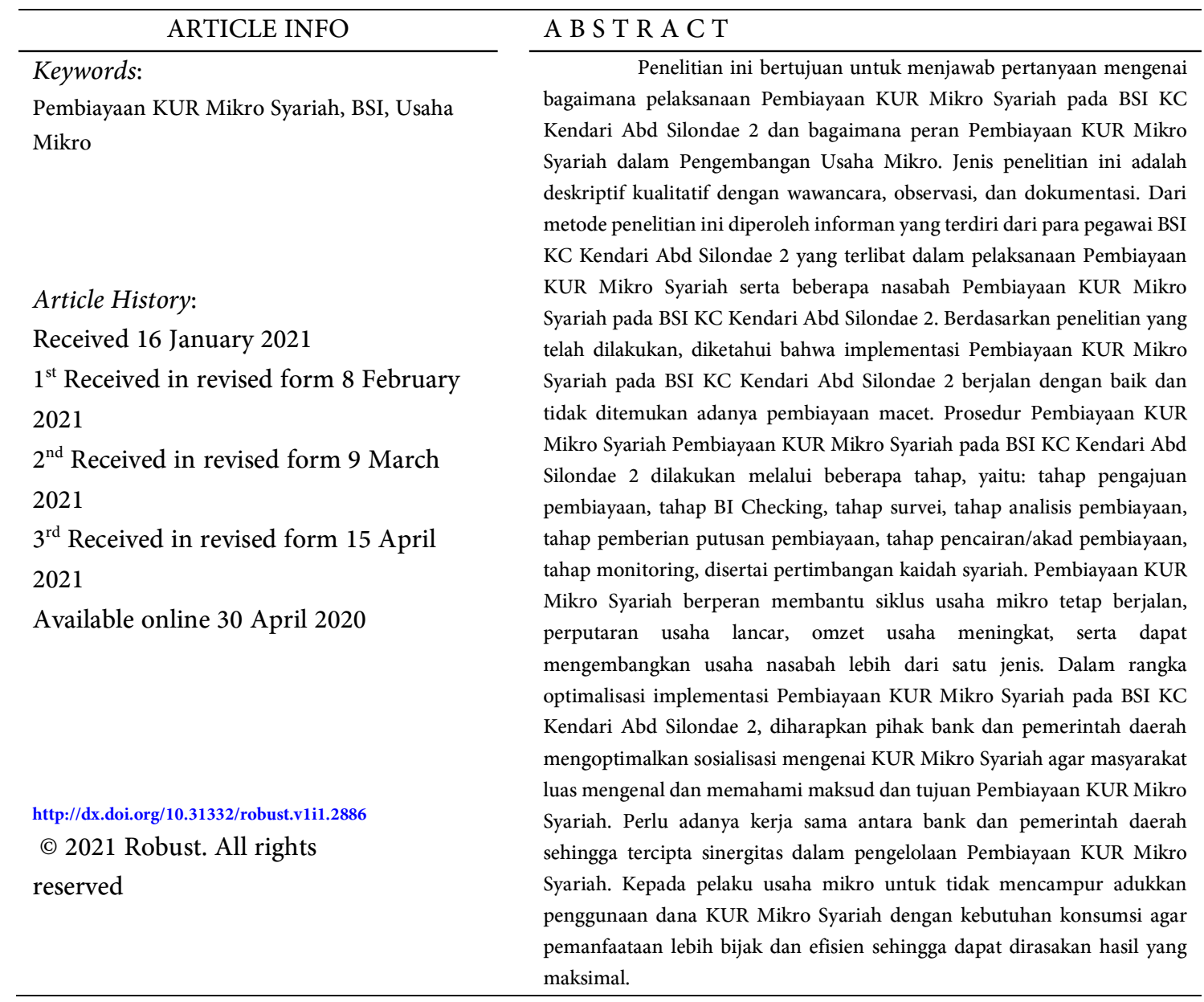


Mongkito, Dkk./Robust-Research Business and Economics Studies, Volume 1 (No.1 2021)

\section{Pendahuluan}

Pelaku usaha di Indonesia dikuasai oleh Usaha Mikro Kecil dan Menengah (UMKM). Usaha Mikro Kecil dan Menengah mampu berdiri kokoh tidak terpengaruh ketika krisis ekonomi tahun 1997-1998 menerpa. Pasca krisis, jumlah Usaha Mikro Kecil dan Menengah tidak berkurang justrusemakin bertambah, bahkan mampu menyerap banyak tenaga kerja. UMKM di Indonesia berkontribusi pagi pertumbuhan enokonomi, penciptaan lapangan kerja dan pendistribusian hasil-hasil bangunan. 98\% perusahaan di indonesia merupakan usaha mikro kecil yang mampu menyumbang 57\% Pendapatan Domestik Bruto (PDB) dan menyerap $60 \%$ tenaga kerja. Usaha Mikro merupakan pemeran utama dalam kegiatan ekonomi di Indonesia.) Modal investasi yang rendah, penyediaan kesempatan kerja, dan output produksi yang tinggi dalam menyumbang Produk Domestik Regional Bruto (PDRB) daerah, pengembangan sektor Usaha Mikro digunakan sebagai penunjang pembangunan ekonomi jangka panjang yang stabil.

Modal merupakan faktor pendukung peningkatan kinerja dan produksi. Pengusaha mikro yang terjebak dalam kebutuhan permodalan seringkali melakukan cara cepat dengan meminta bantuan permodalan kepada rentenir yang pada akhirnya menjerat mereka. Bunga pinjaman yang besar, belum lagi ketika menunda pelunasan, belum mampu melunasi sesuai tempo waktu yang ditentukan, maka hutang semakin lama semakin bertambah. Kemudian berdampak pada hasil usahanya, menurun dan kurang produktif. Bank syariah merupakan lembaga keuangan yang berfungsi sebagai perantara bagi pihak berlebihan dana dan pihak kekurangan dana untuk kegiatan usaha dan kegiatan lainnya yang sesuai dengan hukum islam. Bank syariah dalam istilah internasional dikenal dengan Islamic Banking atau Interest free Banking merupakan suatu sistem perbankan yang dalam pelaksanaan oprasionalnya tidak menggunakan sistem bunga (Riba), Spekulasi (Maysir) dan ketidak pastian atau ketidak jelasan (Gharar).

BRI Syaraiah yang merupakan salah satu lembaga keuangan yang memiliki program pembiayaan tentunya sangat mendukung akan pengembangan para pengusaha mikro, dukungan tersebut direalisasikan dengan mengeluarkan sebuah produk yang berupa pembiayaan bagi para pengusaha mikro dengan diberi nama Unit Mikro Syariah iB yang bertujuan untuk kebutuhan tambahan modal ataupun investasi. Fokus penelitian ini adalah Implementasi pembiayaan kredit usaha rakyat (KUR) mikro syariah pada pengembangan usaha mikro di kota kendari, terkhususnya pada bank BSI KC Kendari Abd Silondae 2. Berdasarkan latar belakang yang dikemukakan, maka masalah yang akan diteliti dirumuskan sebagai berikut: Bagaimana implementasi pembiayaan (KUR) Mikro Syariah di BSI Abd Silondae 2? Bagaimana peran pembiayaan KUR Mikro Syariah dalam pengembangan Usaha Mikro? 
Mongkito, Dkk./Robust-Research Business and Economics Studies, Volume 1 (No.1 2021)

\section{Kajian Pustaka}

\subsection{Penelitian Terdahulu yang Relevan}

Hasil Penelitian Nurul Wardhani (2010) yang berjudul "Pelaksanaan Pemberian Kredit Usaha Rakyat (KUR) pada Bank BRI Unit Kuwarang cabang Gombong Surakarta”, menyatakan bahwa ada beberapa tahapan yang dilalui dalam pelaksanaan pemberian Kredit Usaha Rakyat (KUR) pada Bank Rakyat Indonesia Unit Kuwarasan Cabang Gombong dan permasalahan hukum yang timbul atas pemberian KUR. Tahapan tersebut yaitu permohonan, analisis pembiayaan/ pemeriksaan, pemberian putusan, dan akad kredit/ pencairan, sedangkan permasalahan hukum yang timbul diantaranya adalah kredit macet.Perbedaan penelitian ini dengan penelitian diatas adalah peneliti membahas tentang implementasi dan peran KUR dalam pengembangan usaha mikro. Persamaannya adalah sama-sama membahas tentang pelaksanaan Kredit Usaha Rakyat dengan metode penelitian deskriptif kualitatif.

Hasil penelitian Indrawan Cahyadi (2010) yang berjudul “implementasi Program Kredit Usaha Rakyat dalam Pemberdayaan Ekonomi masyarakat di BRI Unit Godean Yogyakarta”, menyatakan bahwa BRI Unit Godean 1 telah melaksanakan program dari pemerintah untuk pemberdayaan ekonomi masyarakat melalui kredit usaha rakyat. Program Kedit Usaha Rakyat oleh BRI Unit Godean 1 mempunyai prospek ke depan khususnya masyarakat Godean yang menjadi nasabah KUR di BRI unit Godean 1.Sedangkan peneliti membahas tentang implementasi dan peran KUR dalam pengembangan usaha mikro dikota kendari. Persamaannya adalah sama-sama membahas tentang implementasi Kredit Usaha Rakyat dengan metode penelitian deskriptif kualitatif.

Hasil penelitian Adrey Julianus Pinem (2011) yang berjudul “Implementasi Kredit Usaha Rakyat dalam Mengembangkan Usaha Kecil pada bank BRI Unit Pekan Tolan, Kecamatan Kampung Rakyat, Kabupaten labuhan Batu Selatan”, menyatakan bahwa implementasi Kredit Usaha Rakyat oleh Bank Rakyat Indonesia Unit Pekan Tolan sudah berjalan dengan baik dan mampu mengembangkan usaha kecil. Dapat dilihat dari data yang menunjukkan adanya kebijakan-kebijakan yang mendukung implementasi KUR, kapasitas, fasilitas yang diberikan guna mendukung pelaksanaan KUR, kemudahan prosedur atau proses administrasi, memiliki sumber daya manusia yang berkualitas, serta adanya komunikasi yang baik antara pihak bank dengan masyarakat. Sedangkan peneliti membahas tentang implementasi dan peran KUR dalam pengembangan usaha mikro dikota kendari.Persamaannya adalah sama-sama membahas tentang implementasi Kredit Usaha Rakyat dalam mengembangkan usaha dengan metode penelitian deskriptif kualitatif. 
Mongkito, Dkk./Robust-Research Business and Economics Studies, Volume 1 (No.1 2021)

Hasil penelitian Halimah (2012) yang berjudul "Pengaruh Efektifitas, Pengawasan, dan Pembinaan Kredit terhadap Peningkatan Usaha pada Debitur Kredit Usaha Rakyat Mikro BRI Unit Buring Malang” menyatakan bahwa, variabel independen (efektifitas, pengawasan, dan pembinaan) secara simultan berpengaruh terhadap peningkatan usaha. Secara parsial variabel independen yang berpengaruh terhadap peningkatan usaha adalah variabel pengawasan, dan pembinaan sedangkan variabel efektifitas tidak berpengaruh. Sedangkan peneliti membahas tentang implementasi dan peran KUR dalam pengembangan usaha mikro dengan metode kualitatif deskriptif. Persamaannya adalah sama-sama membahas tentang pelaksanaan Kredit Usaha Rakyat.

Hasil penelitian Dewi Anggraini, Syahrir Hakim Nasution (2013) "Peranan Kredit Usaha Rakyat (KUR) bagi Pengembangan UMKM di Kota Medan”, menyatakan bahwa modal KUR berpengaruh signifikan terhadap pertumbuhan pendapatan UMKM di Medan. Faktor paling dominan yang mendorong pengusaha UMKM untuk menggunakan Kredit Usaha Rakyat (KUR) adalah 37,31\% karena tingkat bunga pinjaman BRI yang turun, 29,85\% direkomendasikan oleh teman, 17,91\% administrasi mudah, 7,46\% jangka waktu pelunasan yang lebih lama, dan $7,46 \%$ pelayanan yang baik.Sedangkan peneliti membahas tentang implementasi dan peran KUR dalam pengembangan usaha mikro dikota kendari. Persamaanya adalah samasama membahas tentang Kredit Usaha Rakyat dan pengembangan usaha.

\subsection{Pembiayaan Bank Syariah}

Pembiayan adalah pendanaan yang dikeluarkan untuk mendukung investasi yang telah direncanakan, baik dilakukan sendiri maupun dijalankan oleh orang lain. Penyaluran pembiayaan kepada masyarakat adalah salah satu fungsi pokok bank syariah sebagaimana diatur dalam Undang-Undang Perbankan Syariah Nomor 21 Tahun 2008 dan merupakan salah satu bisnis utama yang menjadi sumber pendapatan utama bank syariah. Pembiayaan bank syariah berbeda dengan kredit pada bank konvensional.

Pembiayaan yang disalurkan bank syariah memberikan manfaat bagi bank sendiri, debitur/nasabah dan pemerintah. Manfaat pembiayaan bagi bank berupa pendapatan margin keuntungan atau bagi hasil sesuai akad pembiayaan yang diperjanjikan sebelumnya antara bank syariah dengan debitur, peningkatan profitabilitas bank, serta kegiatan pembiayaan dapat mendorong peningkatan kemampuan pegawai bank dalam memahami secara rinci aktivits usaha para debitur diberbagai sektor usaha.

Akad atau transaksi yang digunakan pada produk pembiayaan kur mikro syariah yaitu akad murabahah adalah akad pembiayaan suatu barang denganmenegaskan harga belinya kepada pembeli, 
kemudian pembeli membayar dengan harga lebih sebagai keuntungan yang disepakati. Dan didampingi oleh akad wakalah adalah akad pemberian kuasa dari pemberi kuasa kepada penerima kuasa untuk melaksanakan suatu tugas atas nama pemberi kuasa.

\section{Proses Pembiayaan:}

1. Permohonan pembiayaan

2. Pengumpulan data dan invesigasi

3. Analisis pembiayaan

4. Persetujuan pembiayaan

5. Pengumpulan data tambahan

6. Pengikatan

7. Pencairan

8. Monitoring.

\subsection{Kredit Usaha Rakyat (KUR) Mikro Syariah}

Kredit Usaha Rakyat (KUR) Syariah adalah pembiayaan modal kerja atau investasi kepada debitur individu/perorangan khususnya masyarakat ekonomi menengah ke bawah maupun kelompok usaha produktif dan layak namun belum memiliki agunan tambahan atau agunan tambahannya belum cukup. Tujuan KUR Syariah yaitu meningkatkan dan memperluas akses pembiayaan kepada sektor produktif; meningkatkan kapasitas daya saing usaha mikro, kecil, dan menengah; dan mendorong pertumbuhan ekonomi dan penyerapan tenaga kerja. Sumber dana KUR Syariah bersumber dari dana Lembaga Keuangan Syariah penyalur KUR Syariah. Terdapat fasilitas penjaminan pembiayaan dalam KUR Syariah, yaitu Askrindo Syariah dan Jamkrindo Syariah.

Agunan adalah jaminan tambahan, baik berupa benda bergerak maupun benda tidak bergerak yang diserahkan oleh pemilik agunan kepada Bank Syariah dan/atau UUS, guna menjamin pelunasan kewajiban Nasabah Penerima Fasilitas. Agunan pokok KUR Mikro Syariah berupa usaha atau objek yang dibiayai. Sementara, agunan tambahan tidak diwajibkan dan tanpa perikatan. Penyaluran KUR Mikro Syariah diprioritaskan pada usaha produktif yaitu sektor jasa produksi; industri pengolahan; sektor perikanan; sektor pertanian, perburuan, dan kehutanan. Penyalur KUR Mikro Syariah wajib memenuhi porsi penyaluran KUR Mikro Syariah usaha produktif minimal mencapai target porsi penyaluran yang ditetapkan oleh Komite Kebijakan dalam forum Rapat Koordinasi Komite Kebijakan. Penyalur KUR Mikro Syariah dapat 
memberikan pembiayaan multisektor kepada calon penerima yang memiliki usaha lebih dari satu sektor. Hal ini dalam rangka optimalisasi penyaluran KUR Mikro Syariah.

Berikut adalah rincian usaha produktif per sektor ekonomi, sektoryang dibiayai KUR (mengacu pada Laporan Bank Umum Sektor Ekonomi):

1.) Sektor Pertanian

Seluruh usaha di sektor pertanian, termasuk tanaman pangan, tanaman holtikultura, perkebunan, dan peternakan

2.) Sektor Perikanan

Seluruh usaha di sektor perikanan, termasuk penangkapan dan pembudidayaan ikan.

3.) Sektor Industri Pengolahan

Seluruh usaha di sektor industri pengolahan, termasuk industri kreatif di bidang periklanan, fesyen, film, animasi, video, dan alat mesin pendukung kegiatan ketahanan pangan.

4.) Sektor Perdagangan

Seluruh usaha di sektor perdagangan, termasuk kuliner dan pedagang eceran.

5.) Sektor Jasa-jasa

Seluruh usaha di sektor penyediaan akomodasi dan penyediaan makanan; sektor transportasi, pergudangan, dan komunikasi; sektor real estate, usaha persewaan, jasa perusahaan; sektor jasa pendidikan; sektor jasa kemasyarakatan, social budaya, hiburan, perorangan lainnya.

Jenis KUR Syariah:

1. KUR Mikro

2. KUR Kecil

3. Ritel

\subsection{Usaha Mikro}

Usaha mikro adalah usaha produktif milik individu perorangan atau badan usaha perorangan yang memenuhi usaha mikro sebagaimana diatur dalam undang-undang RI Nomor 9 Tahun 1995.

\section{Ciri-ciri Usaha Mikro}

(a) Jenis barang/komoditi usahanya sewaktu-waktu dapat berganti, tidak selalu tetap.

(b) Tempat usaha sewaktu-waktu dapat berpindah tempat.

(c) Belum melakukan administrasi keuangan, bahkan yang sederhana sekalipun, serta tidak memisahkan keuangan keluarga dengan keuangan usaha.

(d) Pengusaha atau sumber daya manusianya berpendidikan rata-rata relatif sangat rendah dan belum memiliki jiwa kewirausahaan yang memadai. 
Mongkito, Dkk./Robust-Research Business and Economics Studies, Volume 1 (No.1 2021)

(e) Umumnya belum mengenal perbankan tetapi lebih mengenal rentenir.

(f) Umumnya tidak memiliki izin usaha atau persyaratan legalitas lainnya termasuk NPWP.

Permasalahan Usaha Mikro

1.) Faktor Internal
(a) Kurangnya permodalan dan terbatasnya akses pembiayaan
(b) Kurangnya transparansi
(c) Kualitas sumber daya manusia

2.) Faktor Eksternal
(a) Terbatasnya sarana dan prasarana usaha
(b) Terbatasnya akses informasi
(c) Terbatasnya akses pasar
(d) Iklim usaha belum sepenuhnya kondusif
(e) Implikasi otonomi daerah
(f) Implikasi perdagangan bebas
(g) Pungutan tidak resmi/liar
(h) Sifat produk dengan ketahanan pendek. 


\section{Metode Penelitian}

\subsection{Jenis Penelitian}

Jenis penelitian yang penulis gunakan adalah penelitian deskriptif kualitatif dengan menggunakan metode penelitan lapangan (field research) yaitu dengan cara mencari data secara langsung di BSI AbdSilondae 2

\subsection{Waktu dan Tempat Penelitin}

1. Waktu Penelitian ini dilaksanakan sejak februari sampai maret 2021.

2. Tempat pelaksanaan penelitian ini yaitu di Bank BSI KC Kendari A Silondae 2 yang beralamat di Jl. Abdullah Silondae, Korumba, Kec. Mandonga, Kota Kendari Sulawesi tenggara 93111

\subsection{Data Dan Sumber Data}

1. Data Primer adalah data dalam bentuk verbal atau kata-kata yang diucapkan secara lisan, gerakgerik atau perilaku yang dilakukan oleh subjek yang dapat dipercaya, yakni informan yang berkenaan dengan variabel yang diteliti.(Suharsimi Arikunto, 2010:22) Yang diperoleh langsung dari manager marketing mikro, head unit, AOM (Account Officer Mikro) dan nasabah yang telah melakukan pembiayaan KUR mikro syaraiah. Sesuai dengan tujuan dalam penelitian ini, maka data yang akan dikumpulkan antara lain mekanisme pemberian, syarat penerima, nasabah/debitur, pelaksanaan pembiayaan Kredit Usaha Rakyat (KUR) Mikro Syariah di BSI, dan pengembangan usaha Mikro.

2. Data Sekunder adalah data yang menunjang data primer dan tersedia dari studi pustaka maupun hasil obervasi. Dalam penelitian ini peneliti membutuhkan pengumpulan data dengan cara mengunjungi perpustakaan, mencari litratur lain dengan menggunakan menida masa (cetak atau elektronik), dari jurnal-jurnal ilmiah yang relevan dengan penelitian atau membaca diinternet yang berhubungan dengan penelitian yaitu KUR Mikro Syariah dan Usaha Mikro, dan website Bank BSI.

\subsection{Teknik Pengumpulan Data}

1. Wawancara yaitu suatu percakapan yang diarahkan pada suatu masalah tertentu dengan proses tanya jawab langsung yang bertujuan untuk mendapatkan suatu informasi masalah tertentu (Masruhan, 2013:235).Dalam teknik pengumpulan data menggunakan wawancara hampir sama dengan kuesioner. Wawancara sendiri dibagi menjadi 3 kelompok, yaitu wawancara terstruktur, wawancara semi-terstruktur, dan wawancara mendalam (Sulistyo dan Basuki, 2006:173).Pengumpulan data dilakukan dengan mengajukan pertanyaan-pertanyaan secara langsung dan terbuka kepada informan atau pihak yang berhubungan dan memiliki relevansi terhadap masalah yang berhubungan dengan implementasi pembiayaan KUR Mikro Syariah dalam pengembangan Usaha Mikro.

2. Observasi adalah pengamatan yang dilakukan dengan sengaja dan sistematis terhadap aktivitas individu atau objek lain yang diselidiki (Ananta Kusuma, 1987:25) Subjek (sebagai responden dalam wawancara atau kuisioner dapat diamati dalam lingkungan kerja sehari-hari. Dalam hal ini penulis 
melakukan observasi untuk mengetahui secara langsung kegiatan pembiayaan KUR Mikro yang dilakukan oleh karyawan BSI.

3. Dokumentasi yaitu metode pengumpulan data yang diperoleh melalui buku-buku, dokumen, dan lain-lain (Amin Tatang M, 1999:135).Dokumen yang digunakanpeneliti disini berupa foto, gambar, serta data-data mengenai Pembiayaan KUR Mikro di BSI. Hasil penelitian observasi dan wawancara akan semakin sah dan dapat dipercaya apabila didukung oleh foto-foto.

\subsection{Metode Analisis data}

1. Editing data, yaitu reduksi data menjadi suatu susunan kalimat yang sistematis

2. Reduksi data, yaitu memeriksa kelengkapan data untuk mencari data yang masih kurang dan mengesampingkan yang tidak relvan.

3. Deskripsi data, yaitu menguraikan data secara sistematis untuk mendeskripsikan pelaksanaan penelitian induksi dan deduktif sesuai dengan sistematika pembahasan.

4. Penarikan kesimpulan, yaitu kegiatan analisis terpenting adalah menarik kesimpulan dan verifikasi. Mula-mula kesimpulan kabur, tapi lama-lama semakin jelas karena data semakin banyak dan mendukung.

\section{Hasil dan Pembahasan}

\subsection{Implementasi Pembiayaan KUR Mikro Syariah pada BSI KC Kendari Abd Silondae 2}

Pengertian KUR Mikro Syariah yaitu program pembiayaan yang digagas pemerintah, disalurkan oleh Bank Syariah Indonesia (BSI) kepada debitur individu/perorangan maupun kelompok usaha produktif dan layak yang belum memiliki agunan tambahan atau agunan tambahannya belum cukup. dengan limit pembiayaan sampai dengan Rp 50.000.000,00 per nasabah. KUR Mikro Syariah ini adalah pembiayaan yang dijamin pemerintah. Untuk melaksanakan penjaminan KUR Mikro Syariah, pemerintah menunjuk perusahaan penjamin yakni PT Penjaminan Jamkrindo Syariah dan PT Jaminan Pembiayaan Askrindo Syariah. Berikut penuturan dari Pak Fahmi selaku AOM Syaraih BSI KC Kendari Abd silondae 2.

Pembiayaan KUR Mikro Syariah dibagi menjadi 2 (dua) menurut jenisnya, yaitu:

a. Pembiayaan Modal kerja

Pembiayaan modal kerja digunakan untuk memenuhi kebutuhan, baik untuk peningkatan produksi maupun keperluan perdagangan dengan jangka waktu pembiayaan maksimal 3 (tiga) tahun.

b. Pembiayaan Investasi

Pembiayaan investasi digunakan untuk memenuhi kebutuhan barang-barang modal serta fasilitas dengan jangka waktu pembiayaan maksimal 5 (lima) tahun. 
Mongkito, Dkk./Robust-Research Business and Economics Studies, Volume 1 (No.1 2021)

Jumlah Nasabah KUR Mikro Syariah

\begin{tabular}{cc}
\hline Tahun & Jumlah Nasabah \\
\hline 2017 & 264 \\
\hline 2018 & 330 \\
\hline 2019 & 350 \\
\hline Total & 944 \\
\hline
\end{tabular}

Prosedur Pembiayaan KUR Mikro Syariah

a.) Tahap Pengajuan Pembiayaan

b.) Tahap BI Checking

c.) Tahap Survei

d.) Tahap Analisis Pembiayaan/ Tahap Analisis Hasil Survei

e.) Tahap Pemberian Putusan Pembiayaan

f.) Tahap Pencairan Pembiayaan/ Akad Pembiayaan

g.) Tahap Pemantauan/ Monitoring

Kendala Penyaluran Pembiayaan KUR Mikro Syariah

Berdasarkan wawancara tersebut ditemukan kendala dalam penyaluran Pembiayaan KUR Mikro Syariah yaitu banyak calon nasabah yang mainsetnya tentang bank syariah disamakan dengang bank konvensional, nasabah juga mengambil uang dengan tujuan dominan kekomsumsi barang padahal tujuan utama KUR adalah untuk modal kerja dan investasi, dan calon nasabah yang mengajukan Pembiayaan KUR Mikro sudah memiliki fasilitas pembiayaan di bank lain dengan tujuan modal kerja dan riwayat pembiayaan nasabah yang pernah ada masalah, baik karena kemacetan atau keterlambatan bayar sehingga proses tidak dapat dilanjutkan. Tidak ditemukan pembiayaan bermasalah dalam Pembiayaan KUR Mikro Syariah di BSI KC Kendari Abd Silondae 2. 


\subsection{Peran Pembiayaan KUR Mikro Syariah Dalam Pengembangan Usaha Mikro}

Berdasarkan hasil pengamatan dan wawancara, diketahui Pembiayaan KUR Mikro Syariah berperan dalam pengembangan usaha mikro. Survei yang dilakukan pihak internal BSI menyatakan bahwa Pembiayaan KUR Mikro sangat berperan. Pembiayaan KUR Mikro Syariah dengan margin ringan dan banyak manfaat. Dengan adanya Pembiayaan KUR Mikro Syariah sektor usaha mikro yang belum bankable bisa mendapatkan fasilitas pembiayaan. Hal ini membantu siklus usaha mikro tetap berjalan, perputaran usaha lancar, dan usahanya meningkat.

Dari penuturan beberapa nasabah Pembiayaan KUR Mikro Syariah menunjukkan bahwa Pembiayaan KUR Mikro Syariah berperan banyak dalam pengembangan usaha mikro. Usaha mikro dapat dengan mudah mendapatkan permodalan, usaha dapat berjalan, omzet pendapatan meningkat, usaha berkembang. Semula hanya usaha kios-kios bisa bertambah usaha jualan gorengan; semula hanya usaha perabut-perabut, berkembang membuka usaha jualan kue; serta ada pula yang dapat membuka usaha agen elpiji.

Data Informasi Nasabah Pembiayaan KUR Mikro Syariah

\begin{tabular}{llccl}
\hline NO & Nasabah & Sebelum & Sesudah & Jangka Waktu \\
\hline $\mathbf{1}$ & Ibu Itaa & 500.000 & 1.500 .000 & Perhari \\
\hline $\mathbf{2}$ & Ibu Nurhati & 900.000 & 1.500 .000 & Perhari \\
\hline $\mathbf{3}$ & Ibu Hayati & 500.000 & 1.000 .000 & Perhari \\
\hline $\mathbf{4}$ & Ibu Mus & 500.000 & 1.000 .000 & Perhari \\
\hline $\mathbf{5}$ & Pak Sunarto & 4.000 .000 & 7.000 .000 & Perbulan \\
\hline $\mathbf{6}$ & Pak Jusnadi & 3.000 .000 & & Perbulan \\
\hline
\end{tabular}

Dari tabel tersebut dapat dilihat peningkatan pendapatan nasabah setelah mengambil KUR mikro syariah, peningkatannya signifikan setelah mendapatkan KUR Mikro Syariah. Hal ini juga menunjukkan terdapat perbedaan terhapat keuntungan penjualan pada UMKM dikota kendari sebelum dan setelah menggunakan KUR Mikro Syariah. 
Mongkito, Dkk./Robust-Research Business and Economics Studies, Volume 1 (No.1 2021)

\section{Kesimpulan}

Berdasarkan hasil dan pembahasan yang telah dipaparkan, diperoleh kesimpulan sebagai berikut (1) BSI KC Kendari Abd Silondae 2 menyalurkan Pembiayaan KUR Mikro Syariah fokus pada usaha mikro sektor perikanan, sektor peternakan, sektor pertanian, sektor industri pengolahan, sektor jasa produksi, dan sektor perdagangan. Prosedur/Proses Pembiayaan KUR Mikro Syariah pada BSI KC Kendari Abd Silondae 2 dilakukan melalui beberapa tahap, yaitu: tahap pengajuan pembiayaan, tahap BI Checking, tahap survei, tahap analisis pembiayaan, tahap pemberian putusan pembiayaan, tahap pencairan/akad pembiayaan, tahap monitoring, disertai pertimbangan kaidah syariah. Implementasi Pembiayaan KUR Mikro Syariah pada BSI KC Kendari Abd Silondae 2 berjalan dengan baik dan tidak ditemukan adanya pembiayaan macet, dilaksanakan secara tepat sasaran sehingga mampu memecahkan permasalahan dengan baik. (2) Pembiayaan KUR Mikro Syariah mengatasi masalah pemodalan yang merupakan faktor utama dalam mengembangkan usaha, berperan membantu siklus usaha mikro tetap berjalan, perputaran usaha lancar,omzet usaha meningkat, serta dapat mengembangkan usaha nasabah lebih dari satu jenis. Account Officer Micro (AOM) yang lebih banyak, berpengalaman dan terbiasa dalam menyalurkan pembiayaan mikro, serta memiliki radius pelayanan yang mendekati lokasi usaha nasabah menjadikan usaha mikro tidak terbatas dalam mendapatkan akses pembiayaan. 


\section{References}

Buku

Amin, Tatang M. Menyusun Rencana Penelitian. Jakarta: Rajawali, 1999.

Antonio, Muhammad Syafi'i. Bank Syariah dari teori ke praktik. Jakarta: Gema Insani Press, 2001.

Ascarya. Akad dan Produk Bank Syariah Jakarta: PT. Raja Grafindo Persada, 2011.

Bungin, Burhan.(2007). Penelitian Kualitatif. Jakarta: Kencana

Dahlan. Ahmad. Bank Syariah Teoritik, Praktik, Kritik. Yogyakarta: Teras, 2012.

Departemen Agama RI. Al-Qur'an dan terjemahnya. Semarang: Toha Putra, 1995.

Ikatan Bankir Indonesia. Mengelola Bisnis Pembiayaan Bank Syariah. Jakarta: Gramedia Pustaka Utama, 2015.

Ismail. Perbankan Syariah. Jakarta: Kencana Prenadamedia Group, 2011.

LPPI dan BI. Profil Bisnis Usaha Mikro Kecil dan Menengah (UMKM). Jakarta: E-Book, 2015.

Meleong, Lexy J. Metode Penelitian Kualitatif. Bandung: PT Sigma, 1996.

Muhammad. Manajemen Bank Syaariah. Yogyakarta: STIM YKPN, 2011.

Mulyati, Etty. Kredit Perbankan Aspek Hukum dan Pengembangan Usaha Mikro Kecil dalam Pembangunan Perekonomian Indonesia. Bandung: PT Revika Aditama, 2016.

Nainggolan, Basaria. Perbankan Syariah di Indonesia. Jakarta: Rajawali Pers, 2016.

Robiyanto, Febra. Akuntansi Praktis untuk Usaha Kecil dan Menengah. Semarang: Studi Nusa, 2004.

Salim, Peter. Kamus Bahasa Indonesia Kontemporer. Jakarta: Modern English Press, 1991.

Sugiyono. Metode Penelitian Kuantitatif, Kualitatif, Dan ReD. Bandung: Alfabeta, 2016.

Suharsimi Arikunto. Prosedur Penelitian: Suatu Pendekatan Praktik. Jakarta: Rineka Cipta, 2010.

Suharsimi Arikunto. Prosedur Penelitian: Suatu Pendekatan Praktik. Jakarta: Rineka Cipta, 2010.

Sulistyo dan Basuki. Metode Penelitian. Jakarta: Wedatama Widya Sastra, 2006.

Undang-Undang RI Nomor 20 Tahun 2008

Undang-Undang RI Nomor 9 Tahun 1995. 71

Zulkifli, Sunarto. Panduan Praktis Transaksi Perbankan Syariah. Jakarta: Zikrul Hakim, 2003.

Jurnal

Agung Maesya, Akbar. Implementasi Kebijakan Program Kredit Usaha Rakyat (KUR) dalam Pengembangan Usaha Mikro Kecil dan Menengah di 72 Kecamatan Warung gunung Kabupaten Lebak. Skripsi (Banten Universitas Sultan Ageng Tirtayasa, 2015).

Anggraini, Dewi dan Nasution, Syahrir Hakim. “Peranan Kredit Usaha Rakyat (KUR) bagi Pengembangan UMKM di Kota Medan (Studi Kasus Bank BRI)”. Jurnal Ekonomi dan Keuangan Vol. 1, No. 3, Februari 2013,diakses dari https://www.neliti.com/journals/jurnal-ekonomi-dankeuangan pada tanggal 10 Januari 2021.

Cahyadi, Indrawan. Implementasi Program Kredit Usaha Rakyat dalam Pemberdayaan Ekonomi Masyarakat Studi BRI Unit Godean 1 Yogyakarta. (Yogyakarta: UIN Sunan Kalijaga, 2010).

Halimah. Pengaruh Efektifitas, Pengawasan, dan Pembinaan Kredit terhadap Peningkatan Usaha (Studi pada Debitur Kredit Usaha Rakyat Mikro Bank Rakyat Indonesia Tbk Unit Buring Malang). Skripsi (Malang: UIN Maulana Malik Ibrahim, 2012).

Julianus Pinem, Adrey. Implementasi Kredit Usaha Rakyat dalam Mengembangkan Usaha Kecil (Studi pada PT. Bank Rakyat Indonesia (Persero) Tbk. Unit Pekan Tolan, Kecamatan Kampung Rakyat, Kabupaten Labuhan Batu Selatan). Skripsi (Sumatera: Universitas Sumatera Utara, 2011).

Sofiah, M. "Mekanisme pembiayaan KUR Mikro syariah untuk pengembangan UMKM”. Skripsi (Semarang: Universitas Islam Negeri Walisongo,2019)

Sugiyono. Metode penelitian kuantitatif kualitatif dan R\&D. Alfabeta, 2011 
Mongkito, Dkk./Robust-Research Business and Economics Studies, Volume 1 (No.1 2021)

Sulistyastuti, Dyah R. "Dinamika Usaha Kecil dan Menengah (UKM): Analisis Konsentrasi Regional UKMdi Indonesia 1999-2001”. Jurnal Ekonomi Pembangunan, 2004, diakses dari https://journal.uii.ac.id./index.php/JEP/article/view/617/543, pada tanggal 15 Desember 2020

Turmudi, Muhamad. “Pembiayaan Mikro BRI Syariah: Upaya Pemberdayaan dan Peningkatan UMKM oleh BRI Syariah Cabang kendari”. Jurnal Ekonomi dan Bisnis islam Vol. 2, No. 2, Desember 2017

Kalsum, Ummi dan Rahmi."Restrukturisasi Pembiayaan Murabahah Bermasalah: Studi Pada BNI Syariah Cabang Kendari”. Jurnal Ekonomi dan Bisnis Islam Vol.2,No.2, Desember 2017

Wardhani, Nurul. Pelaksanaan Pemberian Kredit Usaha Rakyat (KUR) pada Bank Rakyat Indonesia Unit Kuwarasan Cabang Gombong. Skripsi (Surakarta: Universitas Sebelas Maret, 2010).

\section{SUMBER INTERNET}

Academia, “Ada Beberapa Definisi Pengembangan Usaha Menurut Para Ahli”, https://www.academia.edu/8665059/Ada beberapa definisi pengembangan usaha menurut para a hli, (diakses pada tanggal 23 November 2020)

Badan Pusat Statistik, “Statistik UMKM tahun 2012-2013, "dalam www.bps.go.id(diakses pada tanggal 28 November 2020).

BRISyariah, Brosur Pembiayaan KUR Mikro Syariah https://www.idekredit.com/tabel-angsuran-kur-brisyariah/ (diakses pada tanggal 15 Desember 2020)

Kementerian Koordinator Bidang Perekonomian Republik Indonesia, Sekretariat Komite Kebijakan Pembiayaan bagi UMKM, “Kredit Usaha Rakyat (KUR) Syariah". www.kur.ekon.go.id/komitekebijakan (diakses pada tanggal 30 November 2020)

Kredit Usaha Rakyat, “KUR Baru Memperluas Akses Pembiayaan Bagi UMKM”, https://kur.ekon.go.id/kurbaru-memperluas-akses-pembiayaan-bagi-umkm, (diakses pada tanggal 02 Desember 2020).

Media Bisnis UKM Online \& Peluang Usaha, "Cara Mendapatkan Modal dari KUR BRI Syariah", dalam https://goukm.id/modal-kur-syariah-bri, (diakses pada tanggal 02 desember 2020).

Sejarah Bank Syariah Indonesia, https://www.bankbsi.co.id (diakses pada tanggal 13 Maret 2021)

Struktur organisasi BSI, https://www.bankbsi.co.id/company-information/ (diakses pada tanggal 13 Maret 2021) 